\title{
Investigation of Transition Metal Oxide Catalysts for Diesel PM Removal Under Plasma Discharge Conditions
}

\author{
Shin Yamamoto, Shuiliang Yao ${ }^{*}$, Satoshi Kodama, Chieko Mine and Yuichi Fujioka \\ Chemical Research Group, Research Institute of Innovative Technology for the Earth (RITE), 9-2 Kizugawadai, \\ Kizugawa-shi, Kyoto 619-0292, Japan
}

\begin{abstract}
Seven different transition metal oxides $\left(\mathrm{TiO}_{2}, \mathrm{ZnO}, \mathrm{V}_{2} \mathrm{O}_{5}, \mathrm{Fe}_{2} \mathrm{O}_{3}, \mathrm{Co}_{3} \mathrm{O}_{4}, \mathrm{MnO}_{2}\right.$, and $\left.\mathrm{CuO}\right)$ have been investigated for oxidation of diesel particulate matter (PM) under plasma discharge conditions. The experiments were carried out by measuring PM oxidation rates over each catalyst using a batch-type dielectric barrier discharge reactor. It was found that $\mathrm{TiO}_{2}, \mathrm{ZnO}, \mathrm{V}_{2} \mathrm{O}_{5}$, and $\mathrm{Fe}_{2} \mathrm{O}_{3}$ can promote $\mathrm{PM}$ oxidation, among which $\mathrm{Fe}_{2} \mathrm{O}_{3}$ is a most desirable catalyst for PM oxidative removal as $\mathrm{PM}$ oxidation rate promoted by $\mathrm{Fe}_{2} \mathrm{O}_{3}$ is highest under plasma discharge conditions. The mechanism of PM catalytic oxidation over the metal oxides has been suggested to follow the redox catalytic cycles from the correlation of the catalytic oxidation rates with the formation enthalpies per oxygen atom of the catalysts. $\mathrm{O}$ atoms generated by plasma discharges may play an important role in promoting the re-oxidation of the catalysts. The highest catalytic activity for the PM oxidation with $\mathrm{Fe}_{2} \mathrm{O}_{3}$ has been suggested to be due to the balance between the reduction rate and the reoxidation rate within the redox catalytic cycles.
\end{abstract}

Keywords: Transition metal oxide, catalytic oxidation, dielectric barrier discharge, diesel particulate matter, redox catalytic cycle.

\section{INTRODUCTION}

Diesel engines have higher combustion efficiency than gasoline engines. The spread of diesel engines has a beneficial effect on $\mathrm{CO}_{2}$ emission reduction. However, diesel engines emit particulate matter (PM) and nitrogen oxide (NOx) that are harmful to human beings.

Emission regulations for PM and NOx emitted from diesel vehicles have become increasingly stringent globally [13]. After-treatment systems have been desired for current diesel vehicles to satisfy the new emission regulations. Related with the after-treatment system of PM, a diesel particulate filter (DPF) system is known as the most common one $[2,4-7]$. However, the use of DPF results in an increase in the exhaust gas pressure loss due to the PM deposition within the DPF, and in requirement of DPF regeneration by heating to a temperature higher than $600{ }^{\circ} \mathrm{C}$; those create additional fuel consumption which is not acceptable in view of fuel economy. It is also a problem that a lot of noble metal catalysts are used for removing the deposited PM, such noble metal catalysts provide enough activities for the PM removal at a higher temperature than that of the exhaust gases from the diesel engines.

Plasma technologies have a potentiality as an effective method for PM removal [8-10]. We have developed a dielectric barrier discharge (DBD) reactor driven by a pulse power supply as an alternative to the DPF method [11-15]. The mechanism of PM removal is suggested to include two steps; the first step is the PM deposition (precipitation) due to

\footnotetext{
*Address correspondence to this author at the Chemical Research Group, Research Institute of Innovative Technology for the Earth, 9-2 Kizugawadai, Kizugawa-shi, Kyoto 619-0292, Japan; E-mail: yao@ rite.or.jp
}

plasma discharges, and the second step is the PM oxidation by oxygen $(\mathrm{O})$ atoms generated by plasma discharges. Our PM removal system using plasma discharges has been evaluated by Japan Automobile Research Institute. It has been found that the PM emission from a light-duty vehicle installed with a DBD reactor can satisfy the post new longterm emission regulation that will go into effect in 2009 in Japan [16]. The PM deposition in the DBD reactor is a key factor for enhancing PM removal by oxidation, but also the cause increasing pressure loss due to the excess PM deposition. In order to remove the excessively-deposited PM, catalysts are considerable to promote PM oxidation [17, 18]. Unfortunately, catalysts, such as $\mathrm{Fe}_{2} \mathrm{O}_{3}$, have activities at a temperature higher than $500{ }^{\circ} \mathrm{C}$ [19], far higher than the exhaust gas temperature (about $200{ }^{\circ} \mathrm{C}$ ) [16]. The authors have demonstrated the catalysts of activities to promote PM oxidation in presence of $\mathrm{NO}_{2}$ or $\mathrm{O}_{3}$ which can be produced by plasma discharges. It has been found by thermo-gravimetric analysis that transition metal oxides have catalytic activities to PM oxidation and $\mathrm{MnO}_{2}$, for example, has a PM oxidation efficiency higher than the noble metal catalysts even at the exhaust gas temperature [20]. The catalytic activities of these transition metal oxides are considered to change in plasma discharge spaces in which there are many active oxygen species such as $\mathrm{O}$ atoms, $\mathrm{OH}$ radicals, $\mathrm{NO}_{2}$, and $\mathrm{O}_{3}$ and energized electrons and ions, and UV lights generated by plasma discharges. A few studies have reported PM oxidation by $\mathrm{NO}_{2}, \mathrm{O}_{3}$, and $\mathrm{OH}[10,11,21,22]$. However, little knowledge can be found to understand the PM catalytic oxidation under plasma discharge conditions. In this study, we have compared the PM oxidative activities of seven different transition metal oxides under plasma discharge conditions using a batch-type DBD reactor. The mechanism of PM catalytic oxidation under plasma discharge conditions is proposed. 


\section{MATERIALS AND METHODOLOGY}

\section{Catalyst Support on Alumina Plates}

Transition metal oxides were adopted as the main candidates for the PM oxidation catalyst in this study, because these oxides have shown high catalytic activities to diesel PM oxidation owing to redox catalytic cycles [20]. Noble metals were not selected as the candidates because of resource depletion and rising prices. The transition metal oxides in powders were $\mathrm{TiO}_{2}, \mathrm{ZnO}, \mathrm{V}_{2} \mathrm{O}_{5}, \mathrm{Fe}_{2} \mathrm{O}_{3}, \mathrm{Co}_{3} \mathrm{O}_{4}$, $\mathrm{MnO}_{2}$, and $\mathrm{CuO}$. All of these catalyst powders were of commercial origins and used without any treatment. These catalyst powders were supported on surfaces of the alumina plates $\left(50 \times 50 \times 1 \mathrm{~mm}^{3}\right)$ constituting a DBD reactor according to the following procedure (Fig. 1). 1) The alumina plates were degreased by ultrasonic immersion cleaning with acetone for more than one hour, and dried at room temperature. 2) One surface of the alumina plate was coated with approximately $0.4 \mathrm{~mL}$ perhydro-polysilazane $20 \mathrm{wt} \%$ of xylene solution (PHPS; EPN-X200, Exousia) uniformly by spraying; PHPS is marketed as a silica-coating agent, and a pure silica layer is provided on a substrate from PHPS reacting with $\mathrm{H}_{2} \mathrm{O}$ and/or $\mathrm{O}_{2}$ in the atmosphere at a temperature of above $450{ }^{\circ} \mathrm{C}$. 3) Immediately after spraying PHPS, the powder of each catalyst was individually dispersed uniformly by sieve method (\# $250 \mu \mathrm{m}$, w.d. $160 \mu \mathrm{m}$ ) on the PHPS coated surface of the alumina plate. 4) PHPS was hardened by evaporating the xylene solvent in PHPS at 30
${ }^{\circ} \mathrm{C}$ for more than 24 hours. 5) The PHPS-fixed catalyst powder on the alumina plate surface was sintered at $450{ }^{\circ} \mathrm{C}$ for one hour after brushing off unfixed catalyst powder. The specific surface areas of the fixed catalysts were geometrically calculated based on observations with an electronic microscope, because the reaction between PM and a catalyst was a solid-solid reaction and thus roughness of the catalyst should be ignored. The characteristics of fixed catalyst powders are listed in Table $\mathbf{1 .}$

\section{Batch-Type DBD Reactor}

The basic structure of the batch-type DBD reactor was composed with one aluminum plate $\left(30 \times 30 \times 0.3 \mathrm{~mm}^{3}\right)$ and two alumina plates $\left(50 \times 50 \times 1 \mathrm{~mm}^{3}\right)$. The aluminum plate was sandwiched by the two alumina plates as one set. Three sets were arranged in parallel with two discharge gaps of 0.5 $\mathrm{mm}$ by inserting four alumina spacers $\left(50 \times 10 \times 0.5 \mathrm{~mm}^{3}\right)$ as shown in Fig. (2). The two alumina plate surfaces at the middle of the three sets were supported with the catalyst powder. Approximately $2 \mathrm{~mL}$ of $0.1 \mathrm{wt} \% \mathrm{PM} /$ acetone suspension liquid was applied on each alumina plate surface supported with the catalyst powder, where the PM was collected from the exhaust gas of a diesel engine (2C, Toyota). The applied suspension liquid was dried at $100{ }^{\circ} \mathrm{C}$ for 10 hours to remove acetone from the alumina plate surface. The amount of PM deposited on each alumina plate surface is approximately $1.6 \mathrm{mg}$. The aluminum plate at the middle of the three sets was connected to a high voltage (HV) output of

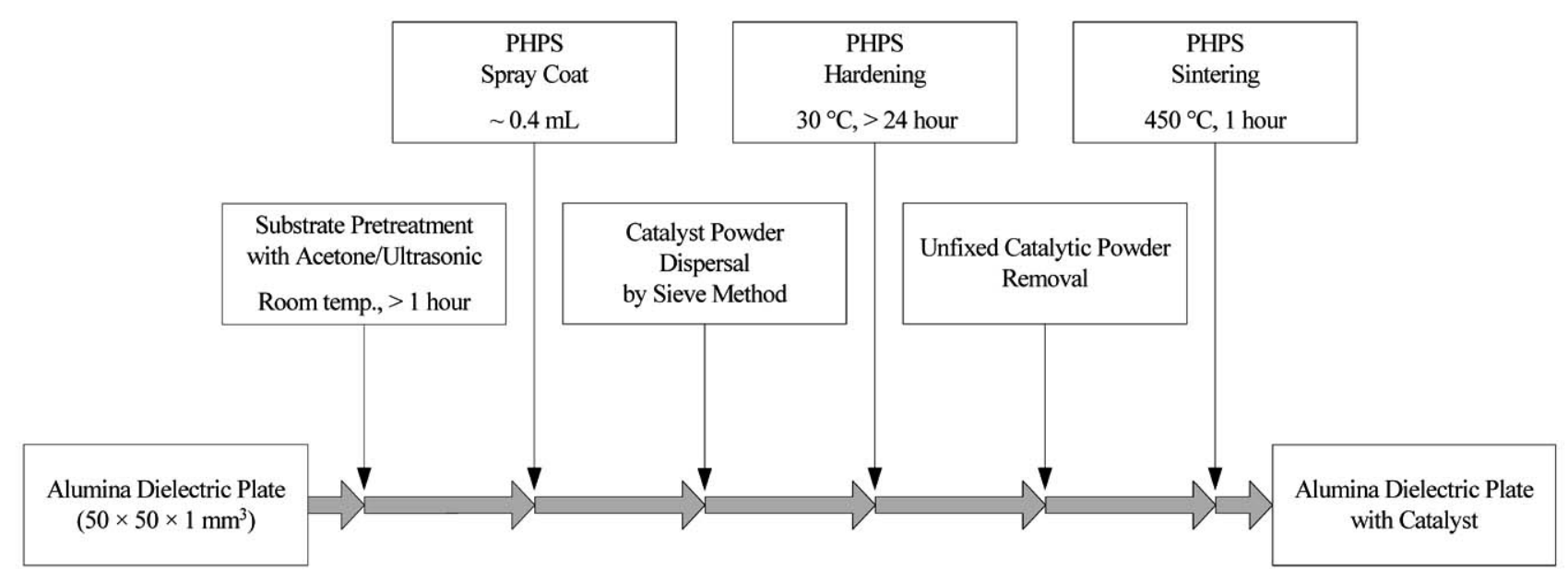

Fig. (1). Procedure of catalyst supporting.

Table 1. Characteristics of Each Catalyst

\begin{tabular}{|c|c|c|c|c|c|c|c|}
\hline & $\mathrm{TiO}_{2}$ & $\mathrm{ZnO}$ & $\mathbf{V}_{2} \mathbf{O}_{5}$ & $\mathrm{Fe}_{2} \mathrm{O}_{3}$ & $\mathrm{MnO}_{2}$ & $\mathrm{Co}_{3} \mathrm{O}_{4}$ & $\mathrm{CuO}$ \\
\hline Manufacturer & Wako & Wako & Wako & Kishida & Wako & Wako & Wako \\
\hline Average Particle Size / $\mu \mathrm{m}$ & 0.17 & 0.30 & 0.27 & 0.18 & 0.20 & 0.26 & 0.22 \\
\hline Specific Surface Area $/ \mathrm{m}^{2} \cdot \mathrm{g}^{-1}$ & 2.70 & 1.46 & 2.87 & 1.94 & 0.80 & 1.35 & 1.39 \\
\hline Formation Enthalpy / kJ.g-O atom $^{-1}$ & -469.9 & -348.3 & -310.1 & -274.7 & -260.0 & -222.8 & -157.3 \\
\hline
\end{tabular}




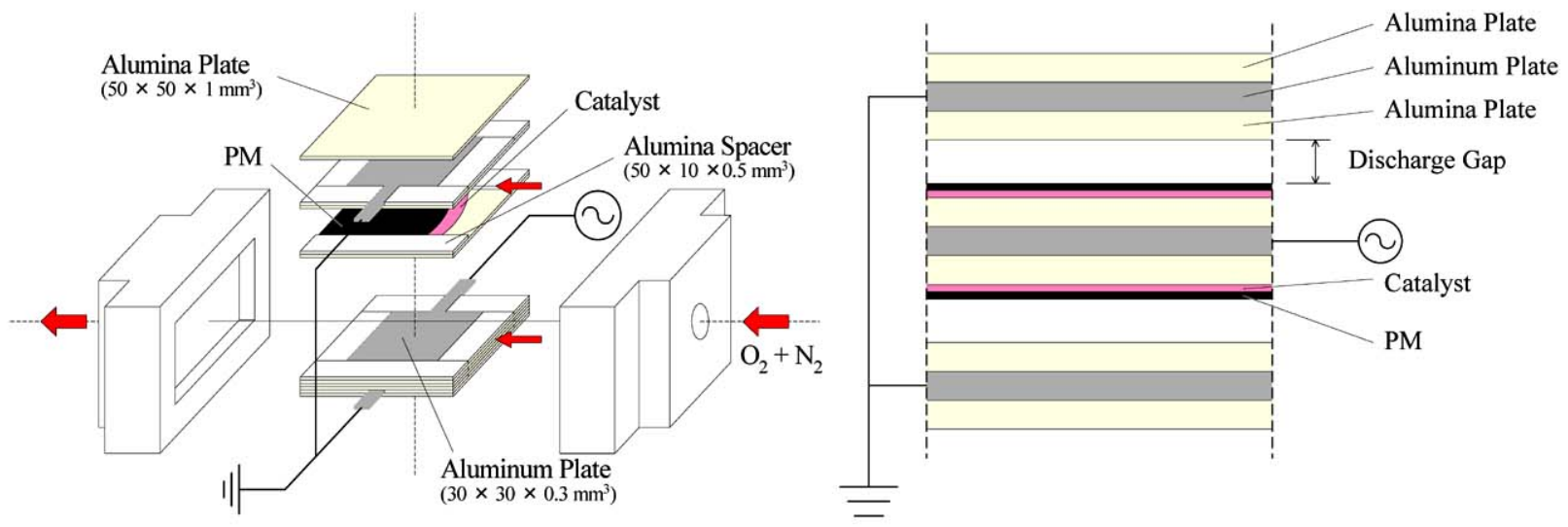

Fig. (2). Basic structure of the DBD reactor.

a pulse power supply and other two aluminum plates were connected to the earth.

\section{Plasma PM Removal System}

A plasma PM removal system including the batch-type DBD reactor is shown in Fig. (3). The batch-type DBD reactor was connected to a pulse power supply (DP-30K10, Pulse Electric Engineering Co.) and the earth. The discharge voltage and currents were measured with a voltage probe (P6015A, Tektronix) and two current probes (TCP202, Tektronix), respectively. The analogue signals from the voltage and current probes were recorded with a digital phosphor oscilloscope (TDS754D, Tektronix). The pulse power supply supplied pulsed voltage of a peak value of $12 \mathrm{kV}$ at a fixed pulse repetition frequency of $200 \mathrm{~Hz}$, resulting in approximately $1.0 \mathrm{~W}$ energy injection into the DBD reactor. A gas mixture of $\mathrm{O}_{2}(10 \%)$ and $\mathrm{N}_{2}$ (balance) was fed into discharge gaps of the DBD reactor at a flow rate of $500 \mathrm{~mL} / \mathrm{min}$ and swept the gas products within the DBD reactor during the PM oxidation by plasma discharges. The DBD reactor and gas lines around it were kept at the reaction temperature of $200{ }^{\circ} \mathrm{C}$ within a thermostatic oven. The gas from the outlet of the DBD reactor was diluted $\mathrm{N}_{2}$ gas $(5.0 \mathrm{~L} / \mathrm{min})$ and then sent into a Fourier-transform infrared spectrometer (FT-IR;

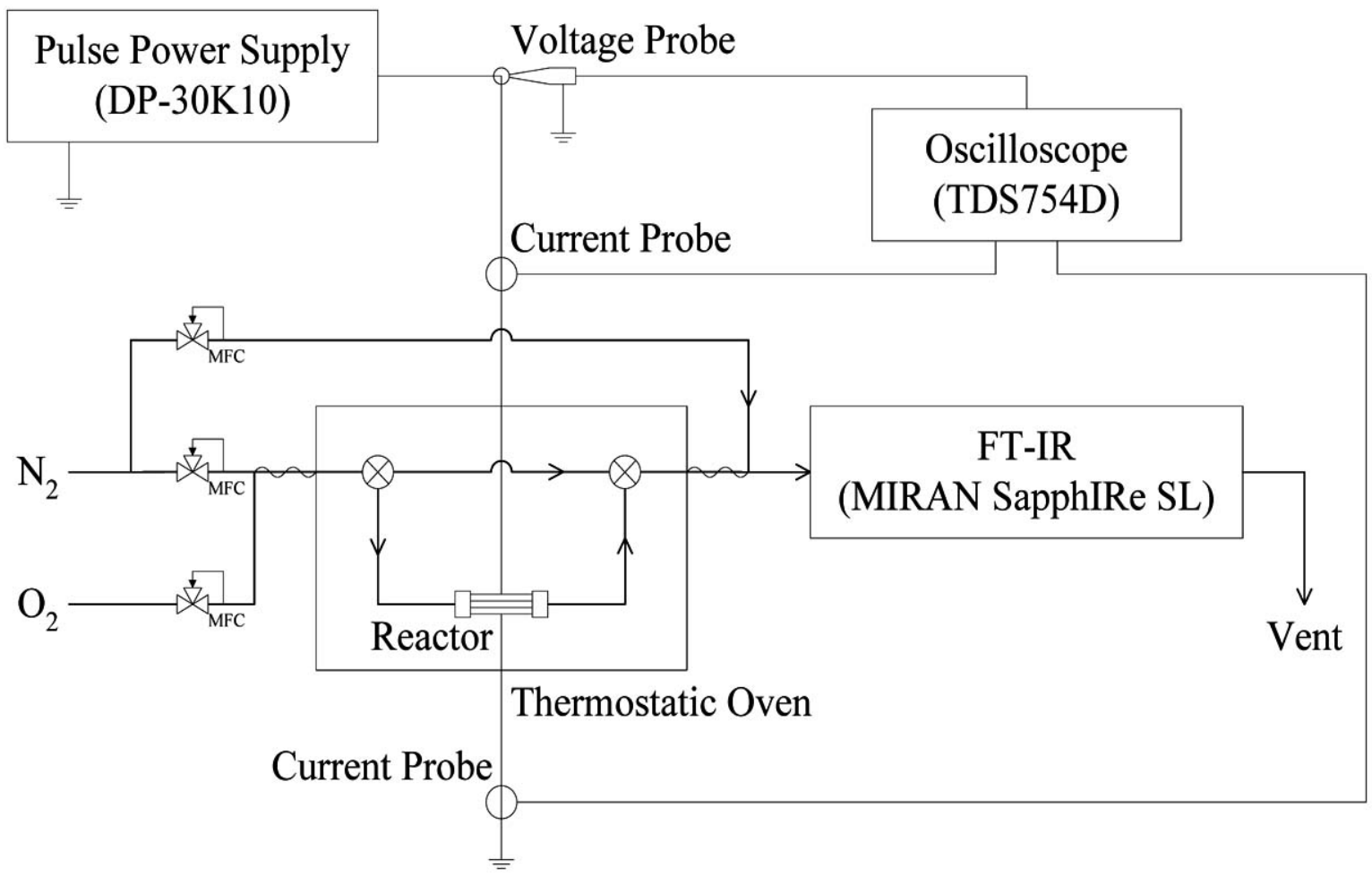

Fig. (3). Schematic of plasma PM removal system. 
MIRAN SapphIRe SL, Nippon Thermo Co.) to measure the concentrations of PM oxidation products.

\section{Definitions}

PM can be oxidized into $\mathrm{CO}$ and $\mathrm{CO}_{2}$ by plasma discharges [12]. The generation rates $r_{i}\left[\mathrm{~mL} \mathrm{~min}^{-1}\right]$ of $\mathrm{CO}$ and $\mathrm{CO}_{2}$ were calculated using equation (1).

$r_{i}=F \cdot C_{i}$

where $F$ is total gas flow rate into the FT-IR analysis cell $\left(5500\left[\mathrm{~mL} \mathrm{~min}^{-1}\right]\right), C_{i}$ is the gas concentration of $i . i$ denotes $\mathrm{CO}, \mathrm{CO}_{2}$ or $\mathrm{CO}+\mathrm{CO}_{2}$.

$\mathrm{PM}$ oxidation rate $r$ [mg-C $\left.\mathrm{min}^{-1}\right]$ was defined as oxidized PM weight per minute which was calculated from the generation rate $r_{\mathrm{CO}+\mathrm{CO} 2}$ using equation (2).

$$
r=\frac{M_{(\mathrm{C})}}{R T} r_{\mathrm{CO}+\mathrm{CO} 2}
$$

where $M_{(\mathrm{C})}$ is molecular weight of carbon $\left[\mathrm{g} \mathrm{mol}^{-1}\right], R$ is the gas constant $\left[\mathrm{L} \mathrm{atm} \mathrm{K} \mathrm{mol}^{-1}\right.$ ], $T$ is the temperature in FTIR analysis cell $[\mathrm{K}]$.

The catalytic oxidation rates $r_{\mathrm{c}}\left[\mathrm{mg}-\mathrm{C} \mathrm{min}^{-1} \mathrm{~mm}^{-2}\right]$ was defined as the differences between the maximum PM oxidation rates with the catalysts $r$ and that without the catalysts $r_{\text {Non }}$ divided by surface areas $S\left[\mathrm{~m}^{2}\right]$ of each catalyst (Table 1) using equation (3).

$r_{\mathrm{c}}=\frac{r-r_{\mathrm{Non}}}{S}$

\section{RESULTS AND DISCUSSION}

Fig. (4) shows the generation rates of $\mathrm{CO}, \mathrm{CO}_{2}$, and the sum of them $\left(\mathrm{CO}+\mathrm{CO}_{2}\right)$ at various elapsed times during the PM oxidation by plasma discharges using the DBD reactor without catalyst support. The plasma discharges began at the elapsed time zero. During the first two minutes, the generation rates of the products increase rapidly, because a respond time of approximately two minutes is required for the FT-IR analysis. The generation rate of $\mathrm{CO}$ is at a level of $0.02 \mathrm{ml}$ $\min ^{-1}\left[20\right.$ to $30 \%$ of the generation rate of $\left.\left(\mathrm{CO}+\mathrm{CO}_{2}\right)\right]$ at an elapsed time longer than 3 minutes. The generation rate $r_{(\mathrm{CO}+\mathrm{CO} 2)}$ peaks at the elapsed time between 15 to 20 minutes, and then decreases gradually. $\mathrm{CO}$ and $\mathrm{CO}_{2}$ are not observable after 180 minutes elapsed time. Actually, at 180 minutes of the elapsed time, $96 \%$ of the carbon balance has been obtained only from integrated products of $\mathrm{CO}$ and $\mathrm{CO}_{2}$, though that at 30 minutes the carbon balance is only $34 \%$.

In order to evaluate the catalytic effect of each catalyst on PM oxidation, we used the PM oxidation rates calculated using equation (2). Fig. (5) shows a comparison of the PM oxidation rates $r$ with and without catalysts. $\mathrm{CuO}, \mathrm{MnO}_{2}$ and $\mathrm{Co}_{3} \mathrm{O}_{4}$ could not promote $\mathrm{PM}$ oxidation. $\mathrm{Fe}_{2} \mathrm{O}_{3}, \mathrm{~V}_{2} \mathrm{O}_{5}, \mathrm{ZnO}$ and $\mathrm{TiO}_{2}$ have catalytic effects on PM oxidation, among which PM oxidation rate with $\mathrm{Fe}_{2} \mathrm{O}_{3}$ is highest. The PM oxidation rate with $\mathrm{Fe}_{2} \mathrm{O}_{3}$ has been improved approximately 34 $\%$ in comparison with that without catalyst.

The comparison of catalytic oxidation rates with each catalyst is shown in Fig. (6). The four metal oxides, $\mathrm{Fe}_{2} \mathrm{O}_{3}$, $\mathrm{V}_{2} \mathrm{O}_{5}, \mathrm{ZnO}$, and $\mathrm{TiO}_{2}$, have positive catalytic oxidative rates under plasma discharge conditions, though the three metal oxides, $\mathrm{CuO}, \mathrm{MnO}_{2}$, and $\mathrm{Co}_{3} \mathrm{O}_{4}$, show negative catalytic oxidation rates. Those findings suggested that $\mathrm{Fe}_{2} \mathrm{O}_{3}, \mathrm{~V}_{2} \mathrm{O}_{5}$, $\mathrm{ZnO}$, and $\mathrm{TiO}_{2}$ are useful to promote PM oxidation and $\mathrm{Fe}_{2} \mathrm{O}_{3}$ is the best catalyst for PM catalytic oxidation removal under plasma discharge conditions.

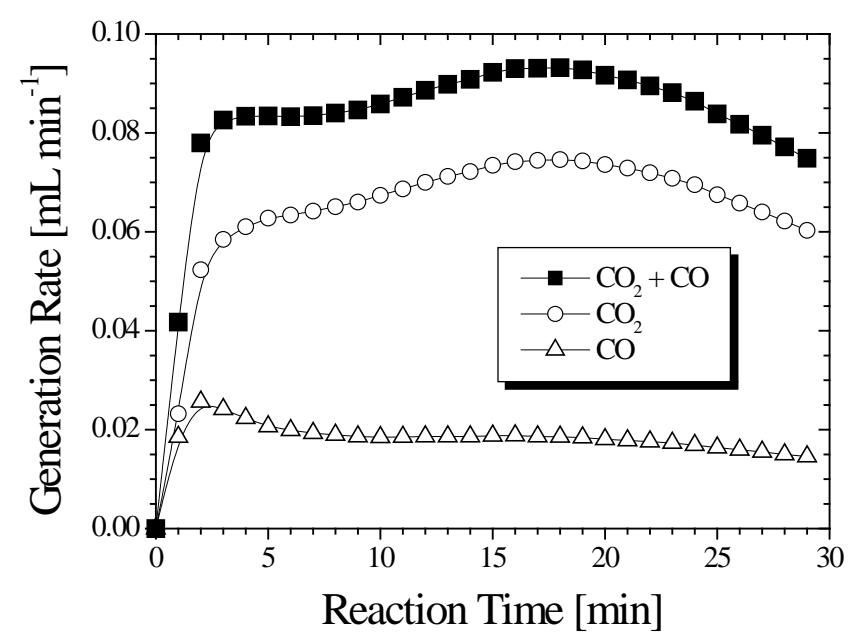

Fig. (4). Generation rates of $\mathrm{CO}$ and $\mathrm{CO}_{2}$ at various elapsed times using the DBD reactor without catalyst support.

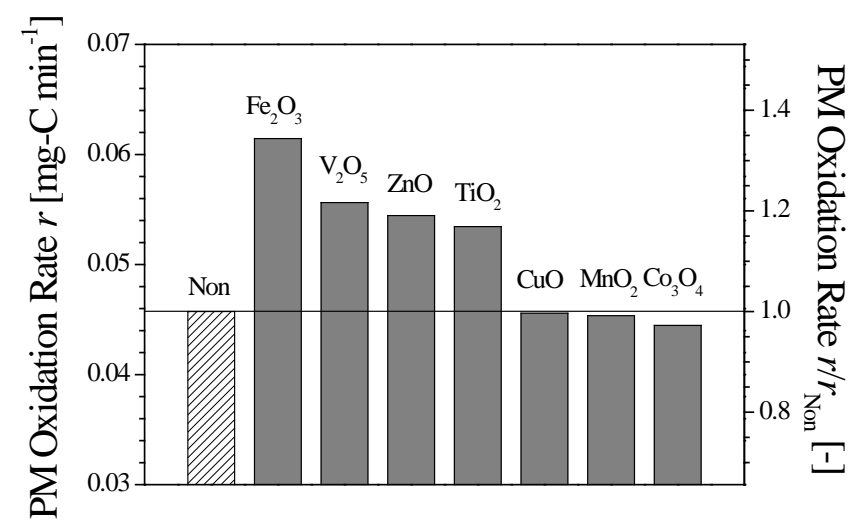

Fig. (5). PM oxidation rates with and without catalysts.

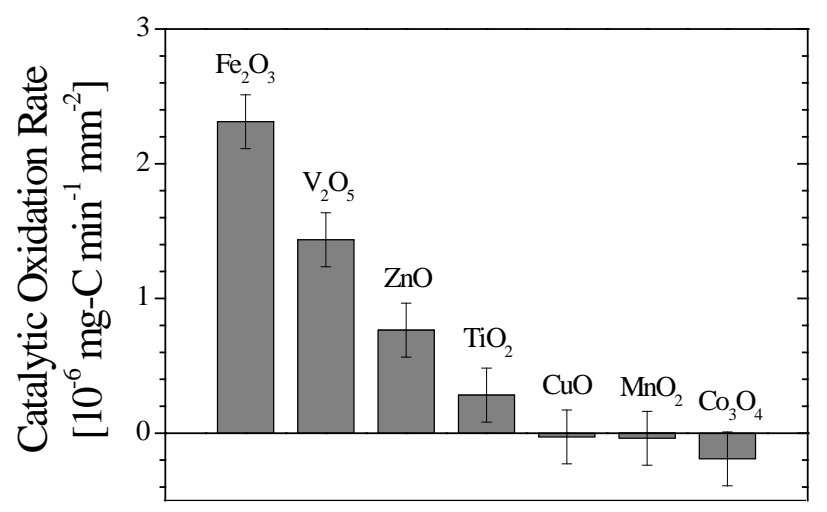

Fig. (6). Comparison of catalytic oxidation rates with each catalyst.

Formation enthalpies per oxygen atom possessed by metal oxides are generally recognized as a measure of oxidative activities of metal oxide catalysts. Fig. (7) shows the catalytic oxidation rates as a function of formation enthalpy per oxygen atom of each catalyst; these values are listed in 
Table 1. The catalytic oxidation rates peak at a formation enthalpy per oxygen atom of approximately $-280 \mathrm{~kJ} \cdot \mathrm{g}$ $\mathrm{O}_{\text {atom }}{ }^{-1}$.

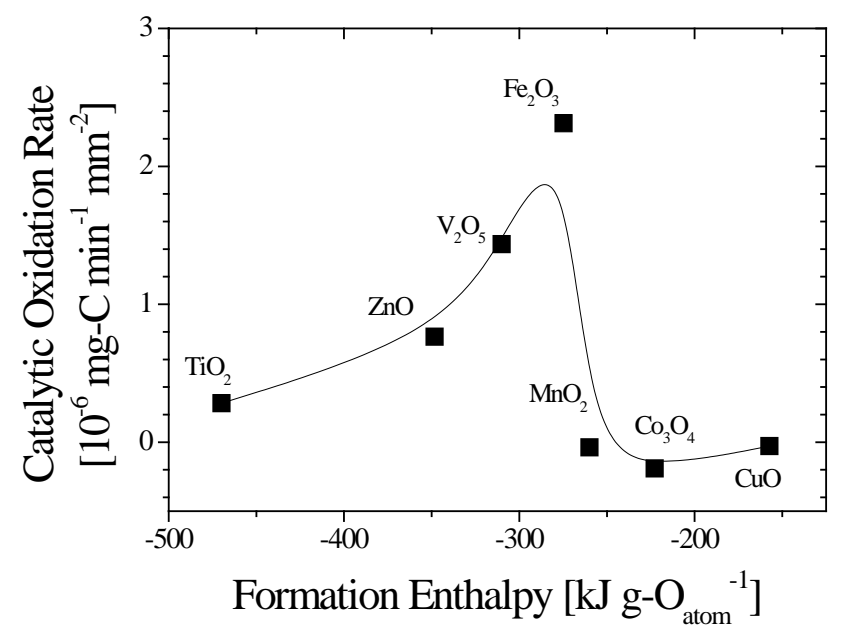

Fig. (7). Relation of catalytic oxidation rates and formation enthalpies of each catalyst.

Related with catalytic oxidation of PM, the redox catalytic cycle is conceivable. Generally, a catalyst composed of a transition metal oxide is reduced to oxidize reactants, and then the reduced metal atom (M) is re-oxidized by oxidants present in the reaction atmosphere; this mechanism is known as a redox catalytic cycle described in the following equations (4) and (5). In plasma discharge space, additional reoxidation reaction is considerable (equation (6)), where $\mathrm{O}$ atoms are generated by plasma discharges.

$$
\begin{aligned}
& \mathrm{M}^{2 \mathrm{n}+} \mathrm{O}_{\mathrm{n}}+\mathrm{C} \rightarrow \mathrm{M}^{2(\mathrm{n}-1)+} \mathrm{O}_{(\mathrm{n}-1)}+\mathrm{CO} \quad \text { (Reduction) (4) } \\
& \mathrm{M}^{2(\mathrm{n}-1)+} \mathrm{O}_{(\mathrm{n}-1)}+1 / 2 \mathrm{O}_{2} \rightarrow \mathrm{M}^{2 \mathrm{n}+} \mathrm{O}_{\mathrm{n}} \quad \text { (Re-oxidation) (5) } \\
& \mathrm{M}^{2(\mathrm{n}-1)+} \mathrm{O}_{(\mathrm{n}-1)}+\mathrm{O} \rightarrow \mathrm{M}^{2 \mathrm{n}+} \mathrm{O}_{\mathrm{n}} \quad \text { (Re-oxidation) }
\end{aligned}
$$

A transition metal oxide of a relatively high formation enthalpy is liable to release the oxygen atoms bound to the metal atom and thus has a higher oxidative activity. If the formation enthalpy of a transition metal oxide is too high, however, the metal atom is poor to be re-oxidized, and therefore such a transition metal oxide has a low activity as an oxidation catalyst because the redox catalytic cycle is difficult to perform. In Fig. (7), the correlation of the catalytic oxidation rates with the formation enthalpies of the catalysts showing a peak (corresponding to $\mathrm{Fe}_{2} \mathrm{O}_{3}$ ) supports the concept that the redox catalytic cycles act practically as the catalytic mechanisms of the transition metal oxides. The presence of $\mathrm{O}$ atoms generated by plasma discharges may play an important role in promoting the re-oxidation of metal under plasma discharge conditions (equation (6)). It is considered that $\mathrm{Fe}_{2} \mathrm{O}_{3}$ has the high catalytic activity for the PM oxidation because the reduction rate and the re-oxidation rate are balanced in performing the redox catalytic cycles under the plasma discharge condition.

It is interesting that those four metal oxides of positive catalytic oxidation rates (Fig. 6) are known to have photocatalytic activities; photo-catalytic reactions possibly occur on the surface of those metal oxides by means of ultraviolet rays generated by the plasma discharges. Here, the negative catalytic oxidation rates with $\mathrm{CuO}, \mathrm{MnO}_{2}$, and $\mathrm{Co}_{3} \mathrm{O}_{4}$ implied that the active oxygen species generated by the plasma discharges have been consumed for oxidizing the catalyst material.

\section{CONCLUSION}

The catalytic activities of the seven transition metal oxides $\left(\mathrm{TiO}_{2}, \mathrm{ZnO}, \mathrm{V}_{2} \mathrm{O}_{5}, \mathrm{Fe}_{2} \mathrm{O}_{3}, \mathrm{Co}_{3} \mathrm{O}_{4}, \mathrm{MnO}_{2}\right.$, and $\mathrm{CuO}$ ) for diesel PM oxidation under plasma discharge conditions have been investigated using a batch-type DBD reactor. $\mathrm{TiO}_{2}$, $\mathrm{ZnO}, \mathrm{V}_{2} \mathrm{O}_{5}$, and $\mathrm{Fe}_{2} \mathrm{O}_{3}$ can promote $\mathrm{PM}$ oxidation, but $\mathrm{CuO}$, $\mathrm{MnO}_{2}$, and $\mathrm{Co}_{3} \mathrm{O}_{4}$ have negative effects on $\mathrm{PM}$ oxidation. The PM oxidation rate with $\mathrm{Fe}_{2} \mathrm{O}_{3}$ is highest in comparison with other metal oxides. From the correlation of the catalytic oxidation rates with the formation enthalpies per oxygen atom of the catalysts, the redox catalytic cycles have been found to act practically as the catalytic mechanisms of the transition metal oxides. $\mathrm{O}$ atoms generated by plasma discharges may play an important role in promoting the reoxidation of metal under plasma discharge conditions. The highest catalytic activity for the PM oxidation with $\mathrm{Fe}_{2} \mathrm{O}_{3}$ has been suggested to be due to the balance between the reduction rate and the re-oxidation rate within the redox catalytic cycles.

\section{ACKNOWLEDGEMENTS}

This work was supported by the New Energy Industrial Technology Development Organization (NEDO) under a government fund from the Ministry of Economy, Trade and Industry, Japan.

\section{REFERENCES}

[1] Chen, S.-J.; Liao, S.-H.; Jian, W.-J.; Lin, C.-C. Environ. Int., 1997, 23, 475-488.

[2] Neeft, J. P. A.; Makkee, M.; Moulijn, J. A. Fuel Process. Technol., 1996, 47, 1-69.

[3] Zelenka, P.; Caretellieri, W.; Herzog, P. Appl. Catal. B-Environ., 1996, 10, 3-28

[4] Oi-Uchisawa, J.; Obuchi, A.; Wang, S.; Nanba, T.; Ohi, A. Appl. Catal. B-Environ., 2003, 43, 117-129.

[5] Ciambelli, P.; Palma, V.; Russo, P.; Vaccaro, S. Catal. Today, 2002, 73, 363-370.

[6] Ciambelli, P.; Palma, V.; Russo, P.; Vaccaro, S. Catal. Today, 2002, 73, 471-478.

[7] Oi-Uchisawa, J.; Obuchi, A.; Enomoto, R.; Xu, J.; Nanba, T.; Liu, S.; Kushiyama, S. Appl. Catal. B-Environ., 2001, 32, 257-268.

[8] Mok, Y. S.; Huh, Y. J. Plasma Chem. Plasma Proc., 2005, 25, 625639.

[9] Chae, J.-O. J. Electrostat., 2003, 57, 251-262.

[10] Dorai, R.; Hassouni, K.; Kushner, M. J. J. Appl. Phys., 2000, 88, 6060-6071.

[11] Yao, S.; Mine, C.; Fushimi, C.; Madokoro, K.; Kodama, S.; Yamamoto, S.; Fijioka, Y.; Kim, Y.-H.; Naito, K.; Fujikawa, H.; Ogawa, T.; Tan, I.; Hasegawa, K.; Tanaka, H. T. Soc. Automot. Eng. Jpn., 2008, 39, 387-392.

[12] Yao, S.; Madokoro, K.; Fushimi, C.; Fujioka, Y. AIChE J., 2007, 53, 1891-1897.

[13] Yao, S.; Fushimi, C.; Madokoro, K.; Yamada, K. Plasma Chem. Plasma Proc., 2006, 26, 481-493.

[14] Yao, S.; Okumoto, M.; Shimogami, J.; Madokoro, K.; Yashima, T.; Suzuki, E. AIChE J., 2004, 50, 715-721.

[15] Yao, S.; Suzuki, E.; Nakayama, A. J. Hazard. Mater., 2001, 83, 237-242.

[16] Yao, S.; Kodama, S.; Yamamoto, S.; Mine, C.; Fujioka, Y.; Fushimi, C. Application of a Dielectric Barrier Discharge Reactor for Diesel PM Removal, Electrostatic Precipitation, The 11th International Conference on Electrostatic Precipitation, Hangzhou, China, 
October 20-24, 2008, Yan K. Eds.; Zhejiang University Press, China, 2008, pp. 677-680.

[17] Neeft, J. P. A.; Makkee, M.; Moulijn, J. A. Appl. Catal. B-Environ., 1996, 8, 57-78.

[18] van Doorn, J.; Varloud, J.; Mériaudeau, P.; Perrichon, V. Appl. Catal. B-Environ., 1992, 1, 117-127.

[19] Reichert, D.; Bockhorn, H.; Kureti, S. Appl. Catal. B-Environ., 2008, 80, 248-259.
[20] Yamamoto, S.; Yao, S.; Kodama, S.; Mine, C.; Fijioka, Y. Chem. Lett., 2008, 37, 998-999.

[21] Harano, A.; Murata, K.; Takamizawa, K.; Sadakata, M. J. Chem. Eng. Jpn., 1998, 31, 700-705.

[22] Grundmann, J.; Müller, S.; Zahn, R.-J. Plasma Chem. Plasma Proc., 2005, 25, 455-466.

(C) Yamamoto et al.; Licensee Bentham Open.

This is an open access article licensed under the terms of the Creative Commons Attribution Non-Commercial License (http://creativecommons.org/licenses/by$\mathrm{nc} / 3.0 /$ ) which permits unrestricted, non-commercial use, distribution and reproduction in any medium, provided the work is properly cited. 